\title{
Reduction of Diuron Efficacy with Biochar Amendments
}

\author{
Chih-Hsin Cheng, Zue-Ping Lin, Yu-Sheng Huang, Chih-Peng Chen, Chie-Te Chen, and Oleg V. \\ Menyailo
}

\begin{abstract}
Amending soil with biochar (BC) can change the sorption properties of soil. However, much of this concern is based on studies from BC produced from wood and crop residues. Since $\mathrm{BC}$ can be made from a wide range of feedstock, it is important to cover all the aspects of feedstock applied as the soil amendments. Six types of feedstock were examined in this study, including a compost, a papermill waste, a leguminous biomass, two bioenergy crop biomass (switchgrass pellet and 3-years-old shrub willow wood chip), and an oak wood biomass. The raw feedstock was pyrolyzed at $300^{\circ} \mathrm{C}$ and $500^{\circ} \mathrm{C}$, respectively. We investigated how feedstock and pyrolytic temperature affect diron sorption and used a bioassay of the BC amendments in a loamy soil to test the change of herbicide efficacy. With the pyolytic temperature increasing, the diuron sorption rate increased. The $300^{\circ} \mathrm{C}$ BCs developed a slightly higher diuron sorption rate than the raw materials, and a considerable enhancement in diuron sorption rate was observed for all $500^{\circ} \mathrm{C}$ BCs. Similar to the sorption capacity of the herbicide, the sequence in reducing herbicide efficacy was $500^{\circ} \mathrm{C}$ $\mathrm{BC}>300^{\circ} \mathrm{C} \mathrm{BC}>$ raw material. Hence, our results suggest that the effect of herbicide effectiveness from $\mathrm{BC}$ amendments can be reduced when raw material is converted into $\mathrm{BC}$, especially the $\mathrm{BC}$ produced at the high temperature $\left(>500^{\circ} \mathrm{C}\right)$.
\end{abstract}

Index Terms -Bioassay, herbicide, NMR, pyrolysis, sorption.

\section{INTRODUCTION}

Biochar (BC) is the byproduct of the pyrolysis of biomass material. Because of its chemically and biologically stable form, $\mathrm{BC}$ can persist in nature for long periods of time. Many researchers have proposed pyrolyzing biomass into $\mathrm{BC}$ as a way to divert carbon (C) from a rapid biological $\mathrm{C}$ cycle into a slow geological $\mathrm{C}$ cycle, and $\mathrm{BC}$ soil amendments can thus effectively sequester atmospheric carbon dioxide in soils [1]. Biochar amendments in soils also provide the agronomical benefits of enhancing soil fertility and increasing crop yield [1], [2], and have recently been implemented in many experiments worldwide [3]-[6].

Comparing to other types of organic matter or soils, BC is known to be a strong sorbent for organic compounds. The sorption of hydrophobic organic compounds by $\mathrm{BC}$ can be 10-1000 times greater than sorption by other types of organic

Manuscript received July 2, 2015; revised September 15, 2015. This study was supported by the Ministry of Science and Technology of Taiwan and a cooperative grant from the Ministry of Science and Technology of Taiwan and the Siberian Branch of the Russian Academy of Sciences (project no. 101-2923-B-002-002).

C. H. Cheng, Z. P. Lin, Y. S. Huang and C. P. Chen are with the School of Forestry and Resource Conservation, National Taiwan University, Taipei, Taiwan (corresponding author; e-mail: chengch@ntu.edu.tw).

C. T. Chen is with the Department of Agronomy, National Chung Hsing University, Taichung, Taiwan.

O. V. Menyailo is with the Institute of Forest SB RAS, Krasnoyarsk 660036, Russia. matter [7] or even up to 400-2500 times more effective than that of soil [8]. Therefore, amending BC in soil may have potential to cause significant changes in the sorption properties of soils. BC amendments may enhance herbicide sorption and affect the efficacy, movement, and degradation of herbicides in soils [9]-[14]. The alteration of herbicide efficacy could be an important topic for weed control in agricultural management practices because farmers would apply more herbicide to BC-amended soils to compensate for its decreased herbicide efficiency. This activity subsequently increases commercial expenses and environmental risk.

Much concern with the alteration of herbicide efficacy by $\mathrm{BC}$ amendment arises from the studies using few type of BC that produced from wood biomass[10], [14] or crop residues [8], [15]. Since BC can be made over a wide range of feedstock, such as the agricultural, municipal, and forestry biomass/wastes [1], [2], it is important to cover all the aspects of feedstock applied as the soil amendments. In addition to the type of feedstock material, the sorptive properties of $\mathrm{BC}$ can differ with the pyrolytical process, especially the temperature experienced during combustion because the high pyrolytic temperature $\left(>500^{\circ} \mathrm{C}\right)$ produces $\mathrm{BC}$ with more carbonization [16]. Such highly carbonized structure of $\mathrm{BC}$ is proposed to be the major sorptive sites for organic compounds [10]. As little information is available to understand the sorption properties for $\mathrm{BC}$ over a range of feedstock along with their pyrolytic temperature, it is required to investigate the sorptive properties of $\mathrm{BC}$ from different feedstock and pyrolytic temperature.

In this study, six types of feedstock including a compost, a papermill waste, a leguminous biomass, two bioenergy crop biomass (switchgrass pellet and 3-years-old shrub willow wood chip), and an oak wood biomass were examined. The raw feedstock was pyrolyzed at $300{ }^{\circ} \mathrm{C}$ and $500{ }^{\circ} \mathrm{C}$, respectively. Our objectives were to investigate how feedstock and pyrolytic temperature affect diuron sorption and to test the change of herbicide efficacy using a bioassay of the $\mathrm{BC}$ amendments in a loamy soil.

\section{MATERIALS AND METHODS}

\section{A. Feedstock}

Six types of feedstock including a compost, a papermill waste, a leguminous biomass, two bioenergy crop biomass (switchgrass pellet and three-year-old shrub willow wood chip), and an oak wood biomass were included in this study.

The compost raw material was the commercial compost made by the spent mushroom compost and swine manure mixtures and composted under the indoor windrow turner for six months. Organic matter content was labelled at $60 \%$ along 
with $2.5 \% \mathrm{~N}, 4.5 \% \mathrm{P}_{2} \mathrm{O}_{5}$, and $0.8 \% \mathrm{~K}_{2} \mathrm{O}$. Papermill waste was collected from Chunghua Paper Co., ltd, located in Hualien County, Taiwan, which produce 150,000 tons paper per years. The feedstock was the mixtures of waste wood bark chip and waste sludge.

Leguminous plant material (Sesbania roxburghii) was collected from the Taoyuan District Agricultural Research and Extension Station in Northern Taiwan. The Sesbania is one of the most common types of leguminous green manure in Taiwan, and is also popular in other tropical and subtropical regions (Palm and Sanchez, 1991). The Sesbania was harvested $50 \mathrm{~d}$ after planting. The plant was at the stage of early blooming, and the mean height was $120 \mathrm{~cm}$.

Bioenergy crop biomass included a switchgrass pellet and a shrub willow wood chip. Switchgrass (Panicum virgatum) and shrub willow (Salix spp.) were planted in the Fingers Lakes regions, New York, USA. Both crops were planted intended for the renewable bioenergy. Mature switchgrass biomass was harvested in fall and pelletized into a $0.7 \mathrm{~cm}$ wide pellet. Shrub willow was harvested at three-year-old, and cut into a $3 \mathrm{~cm}$ long and $1 \mathrm{~cm}$ wide wood chip.

Oak wood was purchased from the commercial red oak (Quercus rubra) firewood. Original wood log was split into a $30 \mathrm{~cm}$ long and $10 \mathrm{~cm}$ wide wood chunk. We further cut the wood chunk into $1 \mathrm{~cm}$ cube before pyrolysis.

\section{B. Pyrolytic Process}

Except of papermill waste that was pyrolyzed at $350{ }^{\circ} \mathrm{C}$ and $500{ }^{\circ} \mathrm{C}$, the feedstock was pyrolyzed at $300{ }^{\circ} \mathrm{C}$ and $500{ }^{\circ} \mathrm{C}$, respectively. Approximately $30 \mathrm{~g}$ of dry raw material was packed into a $300 \mathrm{~mL}$ stainless steel container, loosely sealed with a lid, and pyrolyzed inside a muffle furnace under anoxic condition. The temperature was increased to the desired temperature for $30 \mathrm{~min}$ and held at the desired temperature for $2 \mathrm{~h}$. The produced BC were ground to pass through a $1 \mathrm{~mm}$ sieve for the following analyses. The unconverted raw material was ground as well and used as an unconverted control for comparison with the converted BC samples.

\section{Properties of Raw Material and BC}

To determine the content of $\mathrm{C}, \mathrm{N}$ and $\mathrm{H}$ contents of the raw material and converted $\mathrm{BC}$, the samples were further ground using a ball grinder (Oscillating Mill MM400 by Retsch, PA, USA) and measured using an elemental analyzer (Perkin Elmer 2200, MA, USA) after removing the inorganic $\mathrm{C}$ with $0.1 \mathrm{~N} \mathrm{HCl}$. The ash content was determined using the loss on ignition method, in which the samples were put in a crucible and ignited at $550{ }^{\circ} \mathrm{C}$ for $2 \mathrm{~h}$. The $\mathrm{C}, \mathrm{N}, \mathrm{H}$, and ash contents of the raw material and $\mathrm{BC}$ were presented on a dry basis. The $\mathrm{pH}$ values of the raw material and $\mathrm{BC}$ were measured in 1:20 w/v raw material- or biochar-water mixtures after shaking for $1 \mathrm{~h}$. The specific surface area of BCs was determined from $\mathrm{N}_{2}$ adsorption isotherms at $77 \mathrm{~K}$ using an ASAP 2200 system (Micromeritics, Norcross, GA, USA). Prior to adsorption experiments, the $\mathrm{BC}$ and soil samples were degassed at $378 \mathrm{~K}$ under a pressure of $<10^{-4} \mathrm{~Pa}$ for at least $15 \mathrm{~h}$. Applying the BET model to the $\mathrm{N}_{2}$ adsorption isotherms afforded the specific surface area $\left(\mathrm{S}_{\mathrm{BET}}\right)$.

The chemical structures of the raw material and converted $\mathrm{BC}$ were examined using a solid-state ${ }^{13} \mathrm{C}$ NMR spectrometer.
The solid-state ${ }^{13} \mathrm{C}$ NMR spectra were measured on a Bruker Avance III $400 \mathrm{NMR}$ spectrometer operating at a ${ }^{13} \mathrm{C}$ frequency of $100 \mathrm{MHz}$ with standard ramp cross-polarization magic angle spinning (CPMAS) spectroscopy. The powder sample was packed in a $4 \mathrm{~mm}$ diameter zirconia rotor and spun at a speed of $10 \mathrm{kHz}$. A contact time of $3 \mathrm{~ms}$ and a pulse delay of $1 \mathrm{~s}$ were used for all spectra, and 10,000 scans were accumulated. The chemical shift regions assigned to the major types of C were 0-45 ppm for alky C, 45-110 ppm for O-alkyl C, 110-145 ppm for aryl C, 145-165 ppm for O-aryl C, and 165-190 ppm for carboxyl C [17], [18].

\section{Diuron Sorption Measurements}

Diuron (3-(3,4-dichlorofenyl)-1,1-dimethylurea, >98\% purity), a commonly used non-selective herbicide for pre-emergent and post-emergent weed control, was used as the sorbate to evaluate the herbicide sorption properties on BCs. Two sets of measurements were made. The first set employed a single solution concentration at $20 \mathrm{mg} \mathrm{L}^{-1}$ for determining sorption rate of each raw material and $\mathrm{BC}$. The second set used 5 solution concentrations $(2.5,5,10,15,20$ $\mathrm{mg} \mathrm{\textrm {L } ^ { - 1 }}$ ) to determine sorption isotherms, but were only conducted in the switchgrass pellet, willow wood chip, and oak wood raw material and their BCs. In both sets, the sorption experiments were conducted using the batch equilibrium technique in duplicate. A BC sample weighing $0.01 \mathrm{~g}$ was suspended in $10 \mathrm{~mL}$ aliquots of aqueous sorbent solution containing an initial diuron concentration at $20 \mathrm{mg}$ $\mathrm{L}^{-1}$ or ranging from 2.5 to $20 \mathrm{mg} \mathrm{L}^{-1}$. The aqueous phases received $200 \mathrm{mg} \mathrm{L}^{-1} \mathrm{NaN} 3$ to inhibit aerobic microbial degradation. The suspensions were shaken on a rotary shaker at $120 \mathrm{rpm}$ shaker at $27^{\circ} \mathrm{C}$ in the dark for $24 \mathrm{~h}$. Preliminary kinetic experiments had shown that the sorption of diuron reached equilibrium within $24 \mathrm{~h}$. The solution was then filtered using a $0.45-\mu \mathrm{m}$ membrane (PALL, Millipore Millex-GS; Millipore, Billerca, MA). An aliquot of the filtrate was transferred to an amber vial and analyzed for the remaining amount of each sorbate. Diuron was quantified using high-performance liquid chromatography (HPLC) with a Waters X-Bridge RP-18 TM column and a Water Alliance 2695 series. The mobile phase was 70:30 MeOH: $\mathrm{H}_{2} \mathrm{O}$ (v:v) at a flow of $1 \mathrm{~mL} \mathrm{~min}^{-1}$, and the sample injection volume was 50 $\mu \mathrm{L}$. The UV wavelength used to detect diuron and atrazine was $254 \mathrm{~nm}$.

Because of the minimal sorption of the vials and the apparent lack of biodegradation, the amount of sorbed diuron $\left(Q_{e}, \mathrm{mg} \mathrm{g}^{-1}\right)$ was calculated based on the difference between the equilibrium concentration and the initial concentration, as Eq. (1) shows:

$$
Q_{e}=\left(C_{o}-C_{e}\right)[V / m]
$$

The terms $Q_{e}$ is the amount of sorbed diuron; $C_{o}$ and $C_{e}$ represent the initial and equilibrium concentrations of diuron in the aqueous solution; $V$ is the solution volume; and $\mathrm{m}$ is the weight of the raw material or BC samples. All measurements were conducted in duplicate with a variation generally $<5 \%$, and the average data were reported. The sorption isotherm was fitted with the commonly used Freundlich equations, given as Eqs. (2). 


$$
Q_{e}=K_{f} C_{e}^{n}
$$

The term $Q_{e}$ is the amount of sorbed diuron. $C_{e}$ is the equilibrium concentration. $K_{f}\left([\mathrm{mg} / \mathrm{g}][\mathrm{mg} / \mathrm{L}]^{\mathrm{n}}\right)$ and $\mathrm{n}$ (dimensionless) are the Freundlich parameters of the corresponding system.

\section{E. Biological Assays}

Two diuron levels of 1.5 and $6 \mathrm{mg} \mathrm{kg}^{-1}$ soil were used to assess the effects of herbicide on the growth of ryegrass in soil with and without raw material or BC amendments. The $1.5 \mathrm{mg}$ $\mathrm{kg}^{-1}$ soil was at the low end of the recommended use range, and the $6 \mathrm{mg} \mathrm{kg}^{-1}$ soil was at the high end of the recommended use range. Amendments of raw material, $300^{\circ} \mathrm{C} \mathrm{BCs}$, and $500^{\circ} \mathrm{C} \mathrm{BCs}$ were added to the soil at rates of $1 \%$, respectively. A cultivated soil collected from Taoyung County, Taiwan, at a depth of 0 to $15 \mathrm{~cm}$ served as the control soil [19]. This cultivated soil is developed in an alluvial fan terrace that was derived from Quarternary-aged materials and classified as a Typic Plinthaquic Paleudalf with loam texture and $1.4 \%$ soil organic carbon content.

The diuron was prepared at 60 and $240 \mathrm{mg} \mathrm{L}^{-1}$ solutions in acetone. Five milliliters of diuron solution were added to 200 $\mathrm{g}$ soil with and without $\mathrm{BC}$ amendments to achieve diuron levels of 0 (acetone with no diurion), 1.5 and $6 \mathrm{mg} \mathrm{kg}^{-1}$ soil. The soil was thoroughly mixed and placed into a round plastic pot measuring $10 \mathrm{~cm}$ in width and $8 \mathrm{~cm}$ in height. For each pot, ten pregerminated ryegrass seeds with extended radicles and hypocotyls measuring $5-15 \mathrm{~mm}$ in length were placed evenly on the surface of the soil. The pots were then placed in a completely randomized block design in a greenhouse. The growth of the ryegrass seeds was daily monitored and maintained with adequate water throughout the experiment. The mortality of the ryegrass seeds that influenced by diuron was visually observed starting after 7 days, and the survival rate (no injury) was evaluated after 21 days. A $100 \%$ survival rate indicated no effect of the herbicides, and a $0 \%$ survival rate indicated complete effect of herbicides.Except of papermill waste that was pyrolyzed at $350{ }^{\circ} \mathrm{C}$ and $500{ }^{\circ} \mathrm{C}$, the feedstock was pyrolyzed at $300{ }^{\circ} \mathrm{C}$ and $500{ }^{\circ} \mathrm{C}$, respectively.

\section{RESULTS}

\section{A. Composition and Structure of Raw Material and BCs}

The physical/chemical characteristics of raw material and BCs are tabulated in Table I. Among the selected raw materials, the compost and papermill waste showed the highest ash but least $\mathrm{C}$ contents. The values were much higher/or less than other biomass-based raw materials. High $\mathrm{N}$ content was found in the papermill waste and the sesbania biomass. A higher $\mathrm{pH}$ value was found in the compost and papermill waste that showed the $\mathrm{pH}$ values at 6.9 and 7.0, respectively, compared to other raw materials that had $\mathrm{pH}$ values less than 5.5 .

During the pyrolytical process, the $\mathrm{C}$ content rose as the pyrolytical temperature increased. By contrast, $\mathrm{N}$ and $\mathrm{H}$ contents declined as the pyrolytical temperature increased. These changes in elemental composition were reflected in changes in elemental ratios. The $\mathrm{C} / \mathrm{N}$ ratio rose with the pyrolytical temperature, whereas the $\mathrm{H} / \mathrm{C}$ ratios decreased with the pyrolytical temperature. The ash content and $\mathrm{pH}$ value increased with the pyrolytical temperature (Table I).

The specific surface area showed a significantly low values $<3.0 \mathrm{~m}^{2} \mathrm{~g}^{-1}$ for all raw material and $300^{\circ} \mathrm{C}$ BCs. Higher specific surface area were found in the $500^{\circ} \mathrm{C} \mathrm{BCs}$, especially for the willow wood chip and oak wood $500^{\circ} \mathrm{C} \mathrm{BC}$ that had specific surface area at 101.8 and $227.7 \mathrm{~m}^{2} \mathrm{~g}^{-1}$, respectively.

The NMR spectra indicated the substantial alteration of chemical structure through pyrolysis (Fig. 1). The raw materials were mainly dominated with o-alkyl C, representing the cellulose and hemicellulose structure. With the pyrolytic process, peaks at 50-110 ppm (carbohydrates) and 160-190 ppm (carboxyl) were declined and peaks at 0-50 ppm (alky-C, only for $300^{\circ} \mathrm{C} \mathrm{BC}$ ) and 110-160 ppm (aryl-C or aromatic C) were developed. A dominant peak at $130 \mathrm{ppm}$ was observed for all $\mathrm{BC}$ pyrolyzed at $500^{\circ} \mathrm{C}$, indicating chemical structure in the $500^{\circ} \mathrm{C} \mathrm{BCs}$ was primarily aromatic-C.

\section{B. Sorption to Diuron}

The sorption of diuron at a single concentration solution by raw materials and BCs is shown in Table I. Except the compost raw material that had diuron sorption rate at $1.4 \mathrm{mg}$ $\mathrm{g}^{-1}$, other raw materials displayed the diuron sorption rate below $0.9 \mathrm{mg} \mathrm{g}^{-1}$. The negative value in the papermill waste raw material could be due the release of native organic chemicals during sorption experiment.

With the pyolytic process, the diuron sorption rate increased. The $300^{\circ} \mathrm{C} \mathrm{BCs} \mathrm{developed} \mathrm{a} \mathrm{higher} \mathrm{diuron} \mathrm{sorption}$ rate than the raw materials, and a considerable enhancement in diuron sorption rate was further observed for all $500^{\circ} \mathrm{C} \mathrm{BCs}$. Particularly, the $500^{\circ} \mathrm{C}$ BCs from willow wood chip and oak wood displayed the highest diuron sorption rate at 10.9 and $11.6 \mathrm{mg} \mathrm{g}^{-1}$, respectively.

Sorption isotherms on switchgrass, willow wood chip and oak wood raw materials and their $300^{\circ} \mathrm{C}$ and $500^{\circ} \mathrm{C}$ BCs further corroborated previous results (Fig. 2). Over the range of equilibrium solution concentration, the diuron sorption rate on the $500^{\circ} \mathrm{C} \mathrm{BCs}$ was approximately one order of magnitude greater than raw feedback materials and $300^{\circ} \mathrm{C}$ BCs. The curves of sorption isotherms were well fit to the Freundlich model (Table II), and the model indicated that the diuron sorption isotherm on the $500^{\circ} \mathrm{C} \mathrm{BCs}$ was extremely non-linear, with exponent $n$ value between 0.17 and 0.20 , compared with exponent $\mathrm{n}$ values of between 0.39 and 0.55 and between 0.83 and 0.92 for the $300^{\circ} \mathrm{C} \mathrm{BCs}$ and raw materials, respectively, which indicated a more linear-like sorption isotherm.

\section{Bioassays}

Compared to the soil without amendment that showed non ryegrass seeds survival under diuron application, the amendments of raw organic matter, $300^{\circ} \mathrm{C} \mathrm{BCs}$, and $500^{\circ} \mathrm{C}$ $\mathrm{BCs}$ to soils enhanced the survival rate of ryegrass, a sign of the reduction of diuron efficacy (Table III). At the low end of diuron application $\left(1.5 \mathrm{mg} \mathrm{kg}^{-1}\right)$, the average survival rate for raw material amendment was $50 \%$ and increased to $80 \%$ and $93 \%$ for $300^{\circ} \mathrm{C} \mathrm{BC}$ and $500^{\circ} \mathrm{C} \mathrm{BCs}$, respectively. At the high end of diuron does $\left(6 \mathrm{mg} \mathrm{kg}^{-1}\right)$, much less survival rate was observed. The amendments of raw material showed $<10 \%$ ryegrass seed survival rates; however, the reduction of diuron 
efficacy was still apparent for $500^{\circ} \mathrm{C}$ BCs. Particularly, the amendments of compost, willow, and oak wood $500^{\circ} \mathrm{C}$ displayed $>65 \%$ survival rates.

TABLE I: CHARACTERISTICS FOR RAW MATERIAL, $300^{\circ} \mathrm{C}$ BIOCHAR, AND $500^{\circ} \mathrm{C}$ Biochar of COMPOST, PAPERMILl WASTE, SEsbania Biomass, SWITHCHGRASS PELLET, WILLOW WOOD CHIPS, AND OAK WOOD

\begin{tabular}{|c|c|c|c|c|c|c|c|c|}
\hline & Yield & 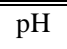 & $\overline{c \mathrm{C}}$ & $\overline{\mathrm{N}}$ & 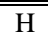 & Ash & \multirow{2}{*}{$\begin{array}{c}\text { Surf. } \\
\text { area } \\
\mathrm{m}^{2} \\
\mathrm{~g}^{-1}\end{array}$} & \multirow{2}{*}{$\begin{array}{c}\text { Diu. }^{a} \\
\mathrm{mg}_{\mathrm{g}^{-1}}\end{array}$} \\
\hline & \multicolumn{2}{|l|}{$\%$} & \multicolumn{4}{|c|}{$\mathrm{mg} \mathrm{g}^{-1}$ (dry mass basis) } & & \\
\hline \multicolumn{9}{|c|}{ Compost } \\
\hline Raw & - & 6.9 & 172 & 24 & 38 & 452 & 0.3 & 1.4 \\
\hline $300^{\circ} \mathrm{C}$ & ND & 7.7 & 207 & 20 & 28 & 488 & 7.7 & 2.4 \\
\hline $500^{\circ} \mathrm{C}$ & ND & 8.8 & 228 & 13 & 13 & 604 & 12.9 & 2.9 \\
\hline \multicolumn{9}{|c|}{ Papermill waste } \\
\hline Raw & - & 7.0 & 295 & 52 & 26 & 319 & 0.3 & -2.1 \\
\hline $350^{\circ} \mathrm{C}$ & ND & 7.2 & 323 & 47 & 40 & 352 & 1.5 & 2.3 \\
\hline $500^{\circ} \mathrm{C}$ & ND & 7.6 & 359 & 44 & 32 & 503 & 7.3 & 2.5 \\
\hline \multicolumn{9}{|c|}{ Sesbania biomass } \\
\hline Raw & - & 5.2 & 487 & 48 & 53 & 100 & 1.2 & 0.2 \\
\hline $300^{\circ} \mathrm{C}$ & 60 & 7.1 & 587 & 41 & 28 & 150 & 2.7 & 4.7 \\
\hline $500^{\circ} \mathrm{C}$ & 35 & 10.7 & 595 & 24 & 8 & 250 & 17.5 & 2.8 \\
\hline \multicolumn{9}{|c|}{ Switchgrass pellet } \\
\hline Raw & - & 5.5 & 434 & 13 & 87 & 65 & 1.1 & 0.9 \\
\hline $300^{\circ} \mathrm{C}$ & 47 & 7.0 & 679 & 8 & 59 & 79 & 1.1 & 1.3 \\
\hline $500^{\circ} \mathrm{C}$ & 27 & 10.0 & 834 & 10 & 41 & 116 & 85.5 & 5.9 \\
\hline \multicolumn{9}{|c|}{ Willow wood chips } \\
\hline Raw & - & 5.1 & 449 & 5 & 91 & 24 & 0.7 & 0.4 \\
\hline $300^{\circ} \mathrm{C}$ & 62 & 6.2 & 571 & 2 & 62 & 31 & 1.2 & 2.9 \\
\hline $500^{\circ} \mathrm{C}$ & 26 & 8.7 & 817 & 3 & 41 & 65 & 101 & 10.9 \\
\hline \multicolumn{9}{|c|}{ Oak wood } \\
\hline Raw & - & 4.5 & 462 & 1 & 85 & 18 & 0.3 & 0.9 \\
\hline $300^{\circ} \mathrm{C}$ & 58 & 4.7 & 601 & 1 & 58 & 20 & 1.0 & 2.3 \\
\hline $500^{\circ} \mathrm{C}$ & 25 & 8.2 & 827 & 2 & 40 & 20 & 227 & 11.6 \\
\hline
\end{tabular}

${ }^{a}$ Diuron sorption at initial concentration at $20 \mathrm{mg} \mathrm{L}^{-1}$

TABLE II: FREUNDLICH PARAMETERS FOR SORPTION ISOTHERM OF DIUON ON RAW MATERIAL, $300^{\circ} \mathrm{C}$ BIOCHAR, AND $500^{\circ} \mathrm{C}$ BIOCHAR OF SWITHCHGRASS PELLET, WILLOW WOOD CHIPS, AND OAK WOOD

\begin{tabular}{lccc}
\hline \hline & $\mathrm{K}_{\mathrm{f}}$ & $\mathrm{n}$ & $\mathrm{R}^{2}$ \\
\hline Switchgrass pellet & & & \\
Raw & 0.08 & 0.83 & 0.99 \\
$300^{\circ} \mathrm{C}$ & 0.48 & 0.55 & 0.95 \\
$500^{\circ} \mathrm{C}$ & 3.43 & 0.20 & 0.99 \\
Willow wood chips & & & \\
Raw & 0.09 & 0.89 & 0.99 \\
$300^{\circ} \mathrm{C}$ & 0.84 & 0.45 & 0.97 \\
$500^{\circ} \mathrm{C}$ & 7.03 & 0.16 & 0.99 \\
Oak wood & & & \\
Raw & 0.09 & 0.92 & 0.95 \\
$300^{\circ} \mathrm{C}$ & 0.80 & 0.39 & 0.94 \\
$500^{\circ} \mathrm{C}$ & 8.92 & 0.17 & 0.99 \\
\hline \hline
\end{tabular}

\section{DISCUSSION AND CONCLUSION}

\section{A. Characterization of Raw Material and Biochar}

Among the selected raw materials, the compost and papermill waste showed the highest ash content and $\mathrm{pH}$ values, which may reflect the additions of alkaline minerals in the spent mushroom wastes and papermill processes or the loss of labile organic matter during compost or management [20]. After pyrolysis, higher $\mathrm{C}$ content and lower $\mathrm{H}$ contents were observed on all BC samples which were consistent with previous studies [16], [17], [21]. The results reflect the thermal dehydration (loss of $\mathrm{H}_{2} \mathrm{O}$ ), demethylation (loss of $\mathrm{CH}_{3}$ ), and decarboxylation (loss of $\mathrm{CO}_{2}$ ) during the pyrolytic process. The increasing ash content with pyrolytic temperature suggests that mineral ash is selectively preserved toward gaseous and liquid products. Because the ash contains mostly bases such as $\mathrm{Ca}, \mathrm{Mg}$, and $\mathrm{K}$, high ash content in the $300^{\circ} \mathrm{C} \mathrm{BC}$ and $500^{\circ} \mathrm{C} \mathrm{BCs}$ is responsible for their high $\mathrm{pH}$ values (Table I) [22].

TABLE III: SURVIVAL RATE (\%) OF RYEGRASS SEEDS IN SOIL UNDER DiURON DOSES (0, 1.5 AND 6 MG/KG) AND BCS AMENDMENTS 3 WEEKS AFTER PLANTING

\begin{tabular}{|c|c|c|c|c|c|c|c|}
\hline & \multicolumn{3}{|c|}{ "Rate of diuron $(\mathrm{mg} / \mathrm{kg})$} & & \multicolumn{3}{|c|}{ Rate of diuron $(\mathrm{mg} / \mathrm{kg})$} \\
\hline & 0 & 1.5 & 6 & & 0 & 1.5 & 6 \\
\hline Control $^{\mathrm{a}}$ & 100 & 0 & 0 & & & & \\
\hline \multicolumn{4}{|l|}{ Compost } & \multicolumn{4}{|c|}{ Switchgrass pellet } \\
\hline Raw & 100 & 90 & 10 & Raw & 100 & 62 & 5 \\
\hline $300^{\circ} \mathrm{C}$ & 100 & 95 & 30 & $300^{\circ} \mathrm{C}$ & 100 & 62 & 33 \\
\hline $500^{\circ} \mathrm{C}$ & 100 & 100 & 65 & $500^{\circ} \mathrm{C}$ & 100 & 84 & 53 \\
\hline \multicolumn{4}{|c|}{ Papermill waste } & \multicolumn{4}{|c|}{ Willow wood chips } \\
\hline Raw & 100 & 40 & 5 & Raw & 100 & 50 & 10 \\
\hline $350^{\circ} \mathrm{C}$ & 100 & 80 & 25 & $300^{\circ} \mathrm{C}$ & 100 & 85 & 40 \\
\hline $500^{\circ} \mathrm{C}$ & 100 & 100 & 30 & $500^{\circ} \mathrm{C}$ & 100 & 95 & 80 \\
\hline Sesbania & \multicolumn{7}{|c|}{ Oak wood } \\
\hline Raw & 100 & 23 & 3 & Raw & 100 & 40 & 5 \\
\hline $300^{\circ} \mathrm{C}$ & 100 & 60 & 27 & $300^{\circ} \mathrm{C}$ & 100 & 95 & 55 \\
\hline $500^{\circ} \mathrm{C}$ & 87 & 88 & 53 & $500^{\circ} \mathrm{C}$ & 100 & 95 & 65 \\
\hline
\end{tabular}

${ }^{\mathrm{a}}$ Control soil without amendment

The decreases in O-alkyl $\mathrm{C}$ and carboxylic $\mathrm{C}$ and the increase in aromatic $\mathrm{C}$ with increasing pyrolytic temperature was consistent with previous studies [16], [17], [21]. The alkyl C structure of the $300^{\circ} \mathrm{C} \mathrm{BCs} \mathrm{samples} \mathrm{resulted} \mathrm{from} \mathrm{the}$ alkyl $\mathrm{C}$ condensation during thermal degradation of the biomass, which was also detected in other biochars produced at lower pyrolytic temperatures [16], [17]. At higher pyrolytic temperatures, the alkyl $\mathrm{C}$ structure is destroyed and a condensed aromatic $\mathrm{C}$ structure is formed.

\section{B. Sorption of Diuron}

The higher sorption capacity of diuron found on $500^{\circ} \mathrm{C} \mathrm{BC}$ is in agreement with studies using the carbonaceous materials [7], [8]. Such high sorption capabilities of diuron on BCs corresponded well with their high aromaticity, in which the aromatic structures grant BC surface to be hydrophobic and therefore enhance diuron sorption through hydrophobic interaction on $\mathrm{BC}$ surface. The formation of aromatic $\mathrm{C}$ also helps delocalize electrons of the basal plane of the $\mathrm{BC}$ surface and enhances the $\pi-\pi$ interaction between the aromatic ring of diuron molecule and the basal planes of the BC surface [23], [24]. In addition, the increase in surface area may be another reason for the higher sorption capacity of diuron on BCs, where the surface area was significantly increased from raw material to $500^{\circ} \mathrm{C} \mathrm{BCs} \mathrm{(Table} \mathrm{I)} \mathrm{[10].} \mathrm{Among} \mathrm{the} \mathrm{raw}$ materials, the compost sample had the highest diuron sorption capacity, which may be due to the formation of humus during composting process that has higher sorption capacity than that of the fresh biomass material [25].

The $500^{\circ} \mathrm{C}$ BCs also exhibit a high nonlinearity. It is because high sorption capacity exists at the lower equilibrium concentration and bend the sorption isotherm toward a nonlinear shape [26], [27]. By contrast, the sorption to the raw material tended to be linear, showing a partition model rather than the sorption [7]. The $300^{\circ} \mathrm{C} \quad \mathrm{BC}$ displayed an intermediate sorptive properties between nonlinear and linear, which the sorption could be contributed by both partition and sorption.

Overall, the results are in agreement with many studies demonstrating that the $\mathrm{BC}$ fraction of soils/sediments with a higher $\mathrm{BC}$ fraction possesses stronger sorption capacity and 
sorption nonlinearity than the non-BC fraction [7], [8], [28], [29]. The high sorption capability of $\mathrm{BC}$ is generally due to its relatively rigid, planar and aromatic surface, whereas the non-BC material is less condensed and consists of more polyanionic macromolecules [7]. Under low temperature $\left(300^{\circ} \mathrm{C}\right)$ pyrolysis, the sorption capacity and sorption nonlinearity of pyrolysis can be greatly altered.
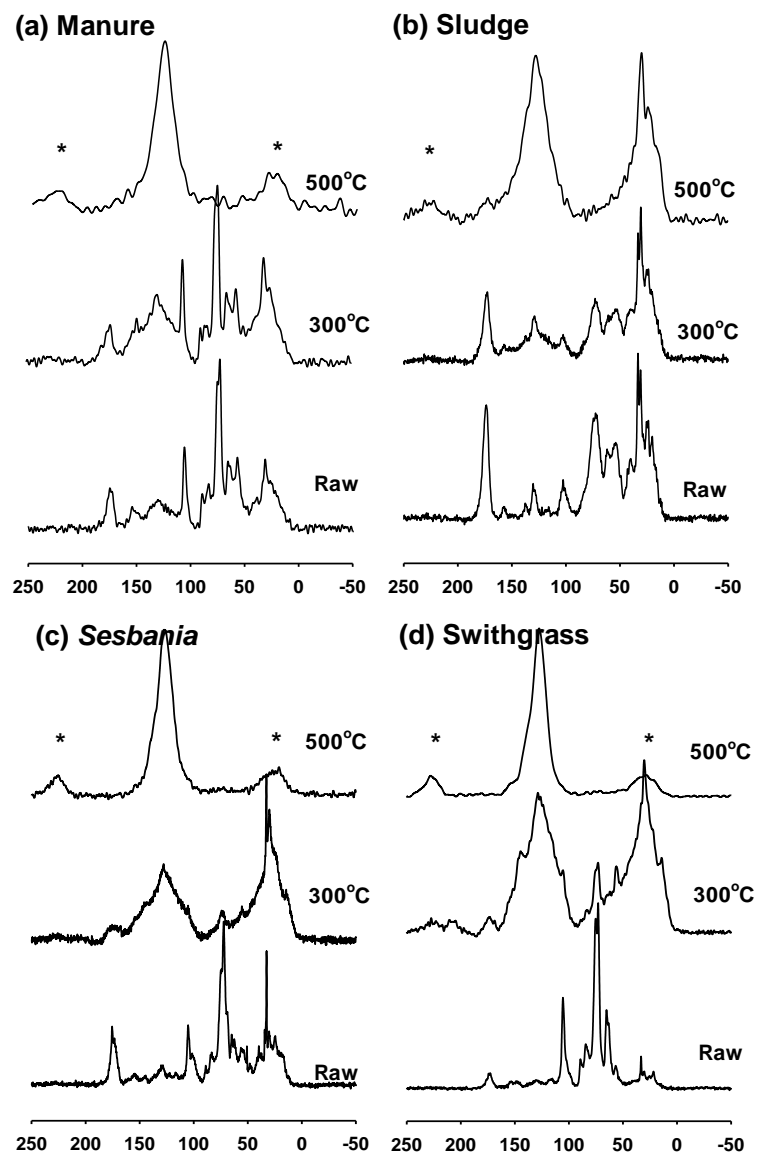

(e) Willow
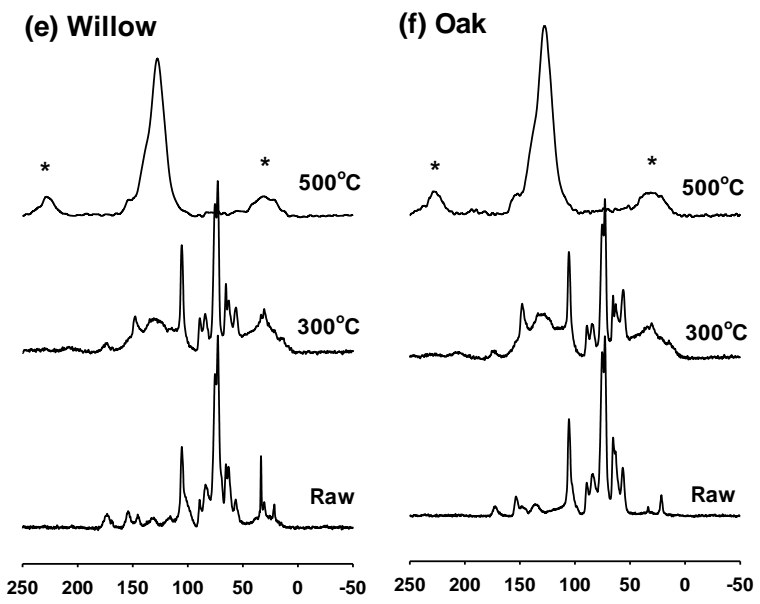

\section{Chemical shift (ppm)}

Fig. 1. Solid state ${ }^{13} \mathrm{C}$ NMR spectra for raw material, $300^{\circ} \mathrm{C}$ biochar, and $500^{\circ} \mathrm{C}$ biochar of (a) compost, (b) papermill waste, (c) sesbania biomass, (d) swithchgrass pellet, (e) willow wood chips, and (f) oak wood. The asterisk refers to spinning side bands at ca. $100 \mathrm{ppm}$ from the dominant aromatic $\mathrm{C}$ resonance at $129 \mathrm{ppm}$.

\section{Reduction of Diuron Efficacy}

The results of the bioassay in herbicide experiments and the results of previous studies suggest that $\mathrm{BC}$ amendments in soils effectively reduce herbicide efficiency [9]-[14], [30]. Similar to the sorption capacity of the herbicide, the sequence in reducing herbicide efficiency was $500^{\circ} \mathrm{C} \mathrm{BC}>300^{\circ} \mathrm{C} \mathrm{BC}>$ raw material. Hence, the effect of herbicide effectiveness from $\mathrm{BC}$ amendments can be reduced when raw material is converted into $\mathrm{BC}$, especially the $\mathrm{BC}$ produced at high temperature $\left(>500^{\circ} \mathrm{C}\right)$.

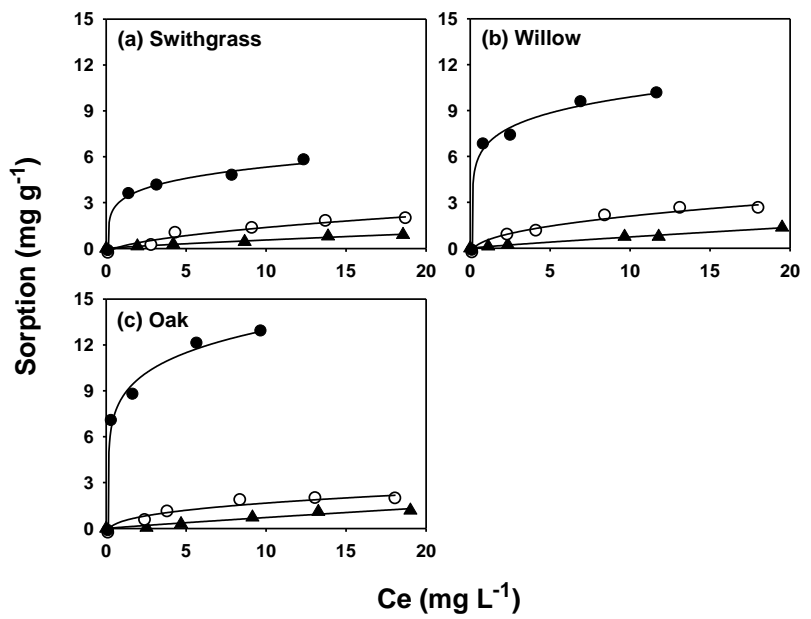

Fig. 2. Sorption isotherm for diuron on raw material, $300^{\circ} \mathrm{C}$ biochar, and $500^{\circ} \mathrm{C}$ biochar of (a) swithchgrass pellet, (b) willow wood chips, and (c) oak wood.

Along with its recalcitrance in environments, the $\mathrm{BC}$ amendment may have a long term effect on herbicide efficacy. Although Cheng et al. (2014) [19] proposed that the effectiveness of herbicide efficacy from BC may decrease with time, the old $\mathrm{BC}$ samples still exist a higher sorption rate than non-BC organic matter [13], [14], [30]-[32]. However, because $\mathrm{BC}$ may be amended periodically in agricultural applications, the aging process of $\mathrm{BC}$ in reducing herbicide inefficacy would become less important.

Although BC amendments inactivate herbicide efficiency, they may have the positive outcome in reducing the risk of environmental contamination and human exposure to contaminants. For example, the amendment of contaminated sediments with $\mathrm{BC}$ has been proposed as a management method to immobilize organic contaminants and biological accumulation in benthic organisms [33].

\section{REFERENCES}

[1] J. Lehmann, "Bio-energy in the black," Frontiers in Ecology and the Environment, vol. 5, pp. 381-387, 2007.

[2] S. P. Sohi, E. Krull, E. Lopez-Capel, and R. Bol, "The review of biochar and its use and function in soil," Advances in Agronomy, vol. 105, pp. 47-82, 2010.

[3] K. Y. Chan, L. Van Zwieten, I. Meszaros, A. Downie, and S. Joseph, "Agronomic values of greenwaste biochar as a soil amendment," Australian Journal of Soil Research, vol. 45, pp. 629-634, 2007.

[4] J. Kimetu, J. Lehmann, S. Ngoze, D. Mugendi, J. Kinyangi, S. Riha, L. Verchot, J. Recha, and A. Pell, "Reversibility of soil productivity decline with organic matter of differing quality along a degradation gradient," Ecosystems, vol. 11, pp. 726-739, 2008.

[5] J. Major, M. Rondon, D. Molina, S. Riha, and J. Lehmann, "Maize yield and nutrition during 4 years after biochar application to a Colombian savanna oxisol," Plant and Soil, vol. 333, pp. 117-128, 2010.

[6] K. A. Spokas, K. B. Cantrell, J. M. Novak, D. W., Archer, J. A. Ipolito, H. P. Collins, A. A. Boateng, I. M. Lima, M. C. Lamb, A. J. McAloon, R. D. Lentz, and K. A. Nichols, "Biochar: a synthesis of its agronomic impact beyond carbon sequestration," Journal of Environmental Quality, vol. 41, pp. 973-989, 2012. 
[7] G. Cornelissen, M. Elmquist, I, Groth, and O. Gustaffson, "Effect of sorbate planarity on environmental black carbon sorption," Environmental Science and Technology, vol. 38, pp. 3574-3580, 2004.

[8] Y. Yang and G. Sheng, "Enhance pesticide sorption by soils containing particulate matter from crop residue burns," Environmental Science and Technology, vol. 37, pp. 3635-3639, 2003.

[9] Y. N. Yang, G. Sheng, and M. S. Huang, "Bioavailability of diuron in soil containing wheat-straw-derived char," Science of Total Environment, vol. 354, pp. 170-178, 2006.

[10] X. Yu, G. Ying, and R. S. Kookana, "Sorption and desorption behaviors of diuron in soils amended with charcoal," Journal of Agricultural and Food Chemistry, vol. 54, pp. 8545-8550, 2006.

[11] R. S. Kookana, "The role of biochar in modifying the environmental fate, bioavailability, and efficiency of pesticides in soils: a review," Australian Journal of Soil Research, vol. 48, pp. 627-637, 2010.

[12] D. L. Jones, G. Edwards-Jones, and D. V. Murphy, "Biochar mediated alterations in herbicide breakdown and leaching in soil," Soil Biology and Biochemistry, vol. 43, pp. 804-813, 2011.

[13] S. K. Nag, R. Kookana, L. Smith, E. Krull, L. M. Macdonald, and G. Gill, "Poor efficiency of herbicides in biochar-amended soils as affected by their chemistry and mode of action," Chemosphere, vol. 84 pp. 1572-1577, 2011.

[14] E. R. Graber, L. Tsechansky, Z. Gerstl, and B. Lew, "High surface area biochar negatively impacts herbicide efficiency," Plant and Soil, vol. 353, pp. 95-106, 2012.

[15] Y. Yang, G. Sheng, "Pesticide adsorptivity of aged particulate matter arising from crop residue burns," Journal of Agricultural and Food Chemistry, vol. 51, pp. 5047-5051, 2003.

[16] C. P. Chen, C. H. Cheng, Y. H. Huang, C. T. Chen, C. M. Lai, O. V. Menyailo, L. J. Fan, and Y. W. Yang, "Converting leguminous green manure into biochar: changes in chemical composition and $\mathrm{C}$ and $\mathrm{N}$ mineralization," Geoderma, vol. 232-234, pp. 581-588, 2014.

[17] J. A. Baldock and R. J. Smernik, "Chemical composition and bioavailability of thermally altered Pinus resinosa (Red pine) wood," Organic Geochemistry, vol. 33, pp. 1093-1109, 2002.

[18] C. H. Cheng, J. Lehmann, J. E. Thies, and S. D. Burton, and M. H. Engelhard, "Oxidation of black carbon by biotic and abiotic processes," Organic Geochemistry, vol. 37, pp. 1477-1488, 2006.

[19] C. H. Cheng, T. P. Lin, J. Lehmann, L. J. Fang, Y. W. Yang, O. V. Menyailo, K. H. Chang, and J. S. Lai, "Sorption properties for black carbon (wood char) after long-term exposure in soils," Organic Geochemistry, vol. 70, pp. 53-61, 2014.

[20] M. L. Cayuela, M. A. Sanchez-Monedero, and A. Roig, "Evaluation of two different aeration systems for composting two-phase olive mill wastes," Process Biochemistry, vol. 41, pp. 616-623, 2006.

[21] M. Keiluweit, P. S. Nico, M. G. Johnson, and M. Kleber, "Dynamic molecular structure of plant biomass-derived black carbon (biochar)," Environmental Science and Technology, vol. 44, pp. 1247-1253, 2010 ,

[22] C. E. Brewer, R. Unger, K. Schmidt-Rohr, and R. C. Brown, "Criteria to select biochars for field studies based on biochar chemical properties," Bioenergy Research, vol. 4, pp. 312-323, 2011.
[23] C. Moreno-Castilla, "Adsorption of organic molecules from aqueous solutions on carbon materials," Carbon, vol. 42, pp. 83-94, 2004.

[24] D. Zhu and J. J. Pignatello, "Characterization of aromatic compound sorptive interactions with black carbon (charcoal) assisted by graphite as a model," Environmental Science and Technology, vol. 39, pp. 2033-2041, 2005

[25] L. Delgado-Moreno, G. Almendros, and A. Pena, "Raw or incubated olive-mill wastes and its biotrandformed products as agricultural soil amendments- effect on sorption-desorption of Triazine herbicides," Journal of Agricultural and Food Chemistry, vol. 55, pp. 836-843, 2007.

[26] Y. Chun, G. Sheng, and G. T. Chiou, "Evaluation of current techniques for isolation of chars as natural adsorbents," Environmental Science and Technology, vol. 38, pp. 4227-4232, 2004.

[27] J. J. Pignatello, S. Kwon, and Y. Lu, "Effect of natural organic substances on the surface and adsorptive properties of environmental black carbon (char): attenuation of surface actvitiy by humic and fulvic acids," Environmental Science and Technology, vol. 40, pp. 7757-7763, 2006

[28] A. Accardi-Dey and P. M. Gschwend, "Assessing the combined roles of natural organic matter and black carbon as sorbents in sediments,' Environmental Science and Technology, vol. 36, pp. 21-29, 2002.

[29] A. Sobek, N. Stamm, and T. D. Bucheli, "Sorption of phenyl urea herbicides to black carbon," Environmental Science and Technology, vol. 43, pp. 8147-8152, 2009.

[30] S. M. Martin, R. S. Kookana, L. V. Zwieten, and E. Krull, "Marked changes in herbicide sorption-desorption upon ageing of biochars in soil," Journal of Hazardous Materials, vol. 231-232, pp. 70-78, 2012

[31] C. H. Cheng, J. Lehmann, "Ageing of black carbon along a temperature gradient," Chemosphere, vol. 75, 1021-1027, 2009.

[32] C. H. Cheng, J. Lehmann, and M. H. Engelhard, "Natural oxidation of black carbon in soils: changes in molecular form and surface charge along a climosequence," Geochimica et Cosmochimica Acta, vol. 72, pp. 1598-1610, 2008.

[33] A. A. Koelmans, M. T. O. Jonker, G. Cornelissen, T. D. Bucheli, P. C. M. Van Noort, and O. Gustafsson, "Black carbon: The reverse of its dark side," Chemosphere, vol. 63, pp. 365-377, 2006.

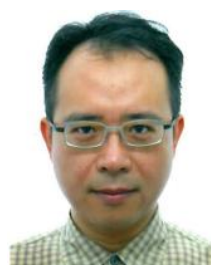

Chih-Hsin Cheng was born in Chang-Hua county, Taiwan. He got his Ph.D. degree from Cornell University, USA, with the doctoral program in crop and soil sciences with distinction of quality in 2007 . $\mathrm{He}$ got his master degree in the Department of Agricultural Chemistry from National Taiwan University in 1996, Taiwan.

$\mathrm{He}$ is a research associate professor in the School of Forestry and Resources Conservation at National Taiwan University, Taiwan. He published several articles related to black carbon (biochar) which had been highly cited. His research topic is soil chemistry, nutrient cycling, and forest biochemistry. Dr. Cheng is a member of the Soil Science Society of America (SSSA) and a member of the American Geophysical Union (AGU). $\mathrm{He}$ is also a member of the Taiwanese Association of Forestry, which serves to the research in soil chemistry and nutrient cycling in Taiwanese forest. 